\title{
Simultaneous determination of newly developed antiviral agents in pharmaceutical formulations by HPLC-DAD
}

\author{
Nourah Zoman Al-Zoman ${ }^{1 *}$, Hadir Mohamed Maher ${ }^{1,2}$ and Amal Al-Subaie ${ }^{1}$
}

\begin{abstract}
Background: Ombitasvir/paritaprevir/ritonavir/dasabuvir (Viekira Pak ${ }^{\circledR}$ ) are the newest medicines approved for use in the treatment of hepatitis $C$ virus (HCV) and are available in tablet form as an oral combination. Specifically, these agents are indicated in the treatment of HCV in patients with genotype 1 infection. Due to the therapeutic importance and increased use of Viekira Pak, proper methods for its determination in bulk and pharmaceutical formulations must be developed.

Results: The present study describes the development and validation of a simple, rapid, selective and economical reverse phase high performance liquid chromatography-diode array detection (HPLC-DAD) method for the simultaneous determination of paritaprevir (PAR), ombitasvir (OMB), dasabuvir(DAS) and ritonavir (RIT) in bulk and pharmaceutical preparations. The proposed method was carried out using an $\mathrm{RPC}_{18}$ column $(150 \times 4.5 \mathrm{~mm}, 3.5 \mu)$, with a mobile phase consisting of $10 \mathrm{mM}$ phosphate buffer ( $\mathrm{pH}$ 7)and acetonitrile $(35: 65, \mathrm{v} / \mathrm{v})$ at a flow rate of $1 \mathrm{ml} / \mathrm{min}$ and a detection wavelength of $254 \mathrm{~nm}$. Sorafenib (SOR) was selected as the internal standard to ensure that the quantitative performance was high. The method was validated based on its specificity, linearity, limit of detection, limit of quantitation, accuracy, precision, robustness and stability. The calibration curves for PAR, DAS, RIT and OMB were linear at $2.5-60,1.25-30,1.7-40$ and $0.42-10 \mu \mathrm{g} / \mathrm{ml}$, respectively, and all of the correlation coefficients were $>0.999$.

Conclusions: The proposed method was successfully applied for the determination of ombitasvir/paritaprevir/ritonavir/dasabuvirin tablets, without interference from the excipient peaks. Hence, the method can be applied for the routine quality control analysis of the studied drugs, either in bulk or dosed forms.
\end{abstract}

Keywords: Antiviral agents, Viekira, HPLC-DAD, Ombitasvir, Paritaprevir, Ritonavir

\section{Background}

Approximately 180 million individuals worldwide are infected with chronic hepatitis $\mathrm{C}$ virus $(\mathrm{HCV})$, and 500,000 patients die each year from liver disease associated with hepatitis $\mathrm{C}$, making it the most common blood borne pathogen [1-3]. HCV, which belongs to the genus Hepacivirus within the family of Flaviviridae, is an enveloped virus with a single positive-stranded RNA genome [4]. In total, six different genotypes of $\mathrm{HCV}$ and multiple subtypes are known, and their distribution varies by

\footnotetext{
*Correspondence: nalzoman@ksu.edu.sa

1 College of Pharmacy, Department of Pharmaceutical Chemistry, King

Saud University, P.O. Box 22452, Riyadh 11495, Saudi Arabia

Full list of author information is available at the end of the article
}

region. In Saudi Arabia, HCV-genotype 4, followed by genotype 1 , are the most prevalent $[3,5]$. Increasing protective immune responses in human beings is difficult using classic approaches for virus control. As a result, an efficient vaccine for the prevention of HCV infection has not yet been developed, and the use of antiviral medications has been the only alternative considered for controlling the HCV epidemic [6]. In the past, a combination of peg-interferon (alfa-2a or alfa-2b) and ribavirin was the only available treatment regimen for $\mathrm{HCV}$. However, these drugs have major disadvantages, such as long treatment courses, suboptimal efficacy, and/or harmful side effects. Therefore, the development of a new category of more potent and safer antiviral agents was required. 


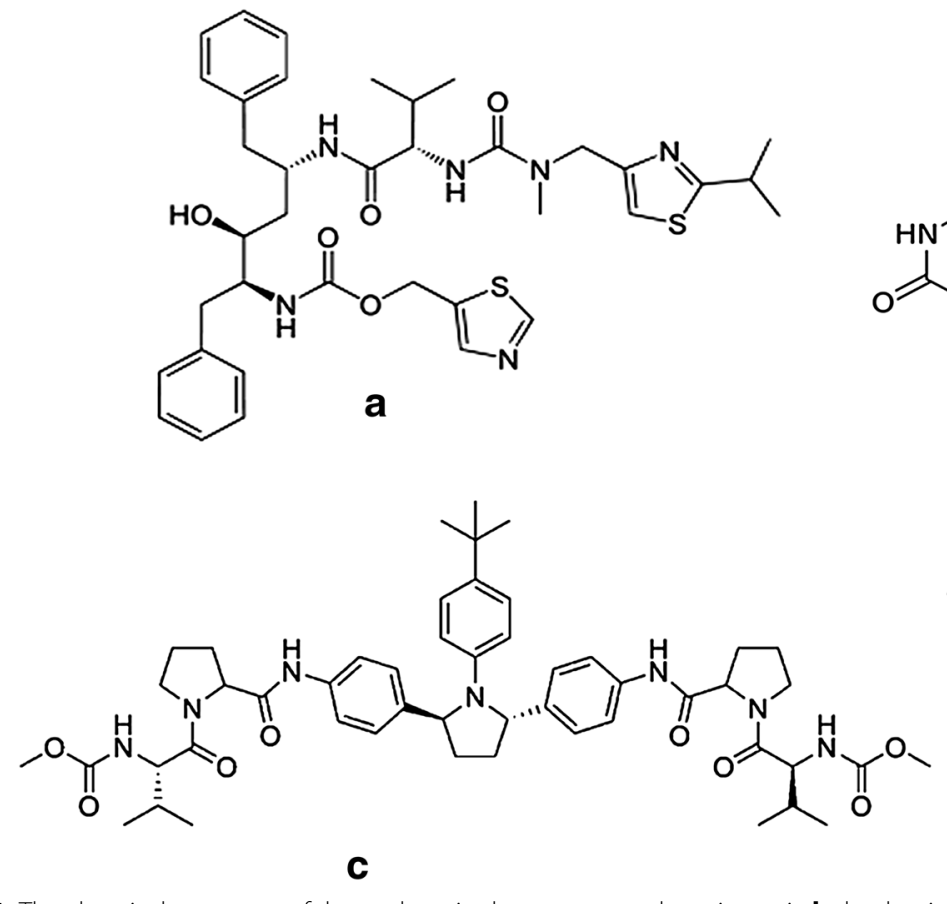<smiles>COc1c(-c2ccc3cc(NS(C)(=O)=O)ccc3c2)cc(-n2ccc(=O)[nH]c2=O)cc1C(C)(C)C</smiles>

b

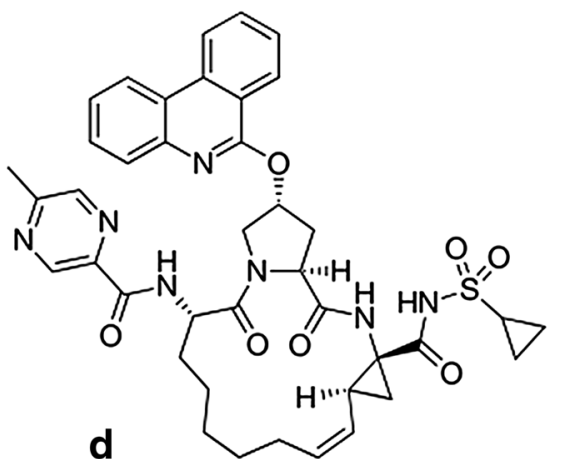

Fig. 1 The chemical structures of the analytes in the present study: a ritonavir; $\mathbf{b}$ dasabuvir; combitasvir; $\mathbf{d}$ paritaprevir

Direct-acting antiviral (DAA) therapies, which were recently discovered and approved, offer good tolerability, short treatment duration, fewer side effects, and high cure rates. DAAs work by targeting a variety of stages in the HCV life cycle [6-11].

On December 19, 2014, Viekira Pak ${ }^{\circledR}$ (a combination of ombitasvir (OMB), paritaprevir (PAR) and ritonavir (RIT) tablets co-packaged with dasabuvir (DAS) tablets; Fig. 1) received FDA approval for the treatment of chronic HCV genotype 1 infection. Ombitasvir is a potent HCV NS5A inhibitor, paritaprevir is a potent inhibitor of NS3/4A protease, dasabuvir is a non-nucleoside NS5B polymerase inhibitor, and ritonavir is used as a pharmacokinetic enhancer for paritaprevir [12, 13]. Subsequently, Technivie ${ }^{\circledR}$ has been approved by the FDA as the first DAA for the treatment of chronic HCV genotype 4 infections without requiring interferon co-administration. Technivie ${ }^{\circledR}$ includes the same drugs as Viekira Pak ${ }^{\circledR}$ with the exception ofdasabuvir [14].

A review of the literature revealed that CE $[15,16]$, HPLC [17-21], UPLC-MS/MS [22-24], LC-MS/MS [25, 26] and HPTLC $[27,28]$ methods have been reported for the analysis of RIT, individually or in combination with other drugs. However, a method for the simultaneous determination of OMB, PAR, RIT and DAS has not yet been reported. Therefore, the purpose of the present work was to develop a new method for the simultaneous determination of OMB, DAS, PAR and RIT in their bulk and pharmaceutical dosage forms. In this report, a simple, rapid, precise, accurate and selective RP-HPLC method was developed and validated in accordance with the international conference on harmonization (ICH) guidelines [29].

\section{Experimental}

\section{Chemicals and reagents}

OMB, DAS, PAR, RIT and internal standard SOR were purchased from Haoyuan Chemexpress Co., Ltd. (Shanghai, China). Samples of Viekirax ${ }^{\circledR}$ and Exviera ${ }^{\circledR}$ tablets were obtained as gifts from King Faisal Specialist Hospital and Research Center (Riyadh, Saudi Arabia) and were manufactured by AbbVie Ltd. Acetonitrile (HPLC gradient-grade) was supplied by Panreac Quimica S.A. (Barcelona, Spain). Potassium dihydrogen orthophosphate anhydrous was obtained from WINLAB (Leicestershire, UK) and sodium hydroxide pellets were supplied by BDH Chemicals Ltd. (Poole, UK). Deionized water was used in all experiments.

\section{Instrumentation and chromatographic conditions}

The HPLC system (Waters, Milford, MA, USA) consisted of a waters 1525 binary HPLC pump, a Waters 2998 Photodiode Array Detector, and a Waters 2707 Autosampler. The data were acquired and processed using Windows XP-based Waters Breeze 2 software. Ultrapure water $(18 \mathrm{M} \Omega / \mathrm{cm})$ was produced by a Milli- ${ }^{\circledR}$ Advantage A10 ${ }^{\circledR}$ Water Purification System (Billerica, MA, USA). 
The chromatographic separations were carried out on a reverse phase Waters Symmetry ${ }^{\circledR} \mathrm{C}_{18}$ column $(150 \times 4.5 \mathrm{~mm}$ i.d., particle size $3.5 \mu \mathrm{m})$. The mobile phase was a mixture of acetonitrile and $10 \mathrm{mM}$ potassium dihydrogen orthophosphate (65:35, v/v; $\mathrm{pH}$ adjusted to 7 with sodium hydroxide) delivered at a flow rate of $1 \mathrm{ml} / \mathrm{min}$. The mobile phase was filtered through $0.45-\mu \mathrm{m}$ Whatman ${ }^{\circledR}$ filterpaper and sonicated for $20 \mathrm{~min}$. Analysis was performed at ambient temperature, and the elution of the compounds was monitored by diode array detection (DAD) from 190 to $400 \mathrm{~nm}$. The chromatograms were recorded at $254 \mathrm{~nm}$, and the injection volume was $20 \mu \mathrm{l}$.

\section{Preparation of standard and sample solutions Preparation of stock solutions}

Accurate aliquots of $10 \mathrm{mg}$ of PAR, RIT, OMB and internal standard SOR were each separately transferred into 10-ml volumetric flasks, dissolved using acetonitrile and diluted up to the mark with the same solvent to obtain primary stock solutions (concentration $1000 \mu \mathrm{g} / \mathrm{ml}$ ) of each drug. The stock solution of DAS was prepared by weighing $10 \mathrm{mg}$ of DAS and dissolving it in a very small amount of DMSO (10 drops); then, the final volume was achieved using acetonitrile to obtain a final concentration of $100 \mu \mathrm{g} / \mathrm{ml}$.

Primary stock solutions of PAR, RIT, OM Band DAS were further diluted with the mobile phase to obtain working standards in the concentration range of 2.5-60, $1.25-30,1.7-40$ and $0.42-10 \mu \mathrm{g} / \mathrm{ml}$ for PAR, DAS, RIT and $O M B$, respectively. A standard concentration of $5 \mu \mathrm{g} /$ $\mathrm{ml}$ SOR (internal standard) was added to the solutions.

\section{Preparation of sample solutions}

Ten tablets of Viekirax ${ }^{\circledR}$ (containing $75 \mathrm{mg}$ PAR, $50 \mathrm{mg}$ RIT and $12.5 \mathrm{mg} \mathrm{OMB}$ ) were weighed and finely powdered. A quantity of the powder equivalent to $10 \mathrm{mg}$ of PAR was weighed and transferred to a $10-\mathrm{ml}$ volumetric flask. A small amount of acetonitrile was added to the flask, and the resulting mixture was sonicated for $20 \mathrm{~min}$. The final volume was achieved using acetonitrile to obtain a final concentration of $1000 \mu \mathrm{g} / \mathrm{ml}$ of PAR. The solution was filtered through $0.45-\mu \mathrm{m}$ filter paper (stock solution A).

Ten tablets of Exviera ${ }^{\circledR}$ tablet (containing $250 \mathrm{mg}$ DAS) were powdered, and an amount equivalent to $10 \mathrm{mg}$ of DAS was accurately weighed into a $10-\mathrm{ml}$ volumetric flask and mixed with 10 drops of DMSO. A small amount of acetonitrile was then added to this flask. The solution was ultra sonicated for $20 \mathrm{~min}$ and filled with acetonitrile to obtain a final concentration of $1000 \mu \mathrm{g} / \mathrm{ml}$ of DAS. The solution was filtered through a $0.45-\mu \mathrm{m}$ membrane filter (stock solution B).
Aliquots of sample stock solutions. A and B were further diluted with the mobile phase, and a constant amount of $5 \mu \mathrm{g} / \mathrm{ml}$ of SOR was added to each solution to obtain final concentrations of $40 \mu \mathrm{g} / \mathrm{ml}$ of PAR, $26.7 \mu \mathrm{g} /$ $\mathrm{ml}$ of RIT, $6.7 \mu \mathrm{g} / \mathrm{ml}$ of OMB and $15 \mu \mathrm{g} / \mathrm{ml}$ of DAS. The resulting solutions were then subjected to analysis by the proposed HPLC method.

\section{Results and discussion \\ Method development and optimization of chromatographic conditions}

The method was developed based upon the experience obtained from the HPLC method previously developed for the analysis of RIT [17]. The previous experiment was performed using a mobile phase consisting of acetonitrile and phosphate buffer $(\mathrm{pH} 3)$ at a ratio of $60: 40, v / v$. For the separation of RIT from mixtures containing DAS, OMB and PAR, methanol and acetonitrile were used as organic modifier, peak symmetry and optimum pressure was obtained by using acetonitrile. Various ratios of acetonitrile and phosphate buffer solutions and different mobile phase $\mathrm{pH}$ values were tested using a C18 $(150 \times 4.5 \mathrm{~mm}, 3.5 \mu \mathrm{m})$ column, higher acetonitrile ratio resulted in shorter retention times of drugs Using this mobile phase ratio best results were obtained in terms of peak symmetry, selectivity and analysis time for drugs and the results are shown in Fig. 2. The pKa values of the studied drugs are reported in the literature as 2.8 for RIT, 2.5 for OMB, 4.6 for PAR, and 8.2 and 9.2 for DAS, which has two pKas. Therefore, the $\mathrm{pH}$ of the mobile phase was adjusted to 7 (Fig. 3). A wavelength of $254 \mathrm{~nm}$ was selected for the simultaneous determination of HVC drugs with high sensitivity. Moreover, the strength of the phosphate buffer solution (10-100 mM) was evaluated. Good resolution and reasonable retention times were observed for all of the drugs when acetonitrile:phosphatebuffer $(0.01 \mathrm{M})(65: 35, \mathrm{v} / \mathrm{v})$ was delivered at a flow rate of $1 \mathrm{ml} / \mathrm{min}$ (Fig. 4).

\section{Method validation}

Validation of the optimized method was performed according to ICH Q2 (R1) guidelines [29]. The following validation characteristics were addressed: specificity, detection limit, quantitation limit, linearity, precision, accuracy and robustness.

\section{System suitability parameters}

System suitability tests are used to verify that the resolution and reproducibility of the system are adequate. Several suitability parameters, including the capacity factor, selectivity, efficiency, resolution and tailing factor were calculated, as shown in Table 1 . The peaks obtained were sharp and showed clear baseline separation. 


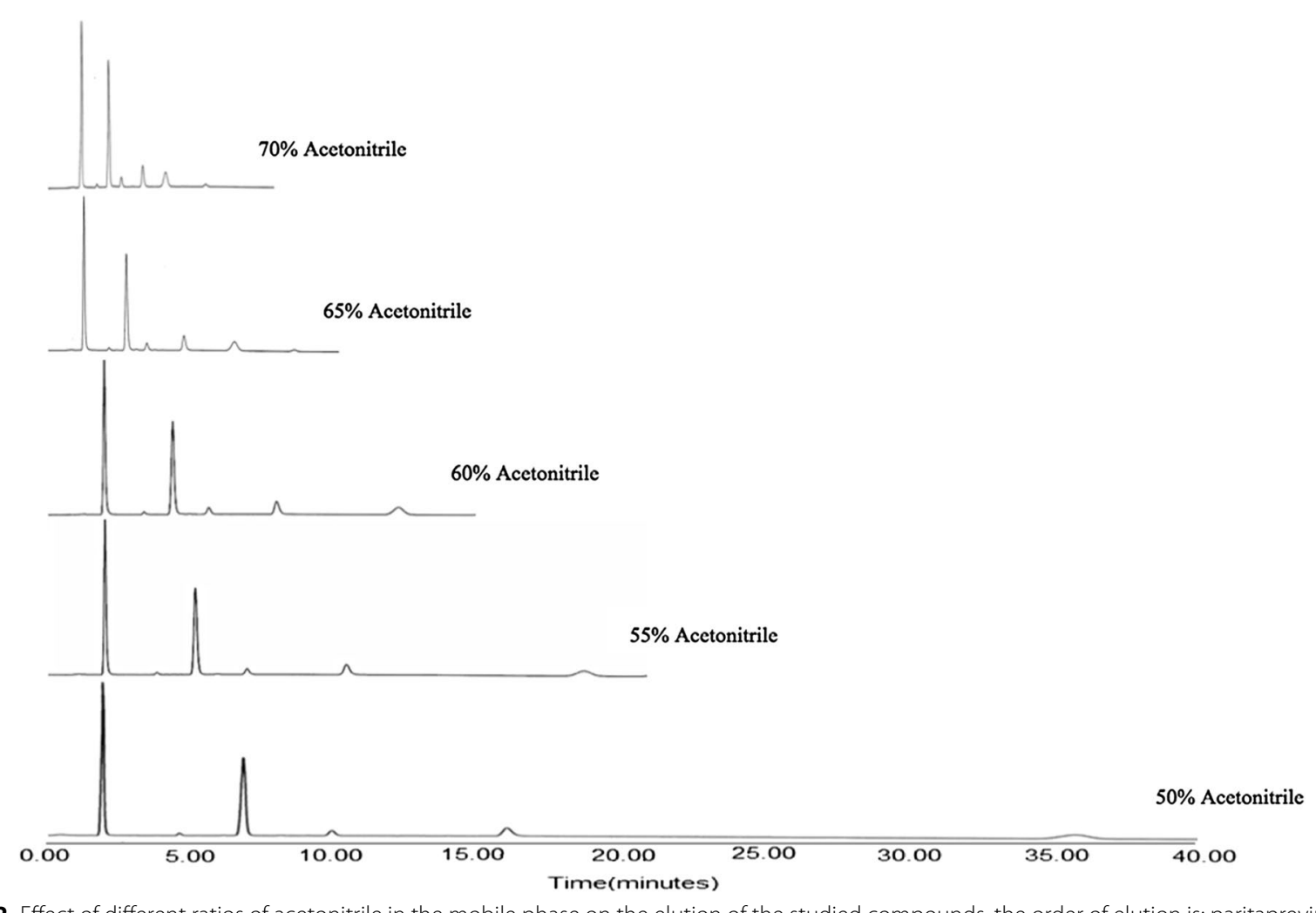

Fig. 2 Effect of different ratios of acetonitrile in the mobile phase on the elution of the studied compounds, the order of elution is: paritaprevir (PAR), dasabuvir (DAS), ritonavir (RIT), and ombitasvir (OMB)

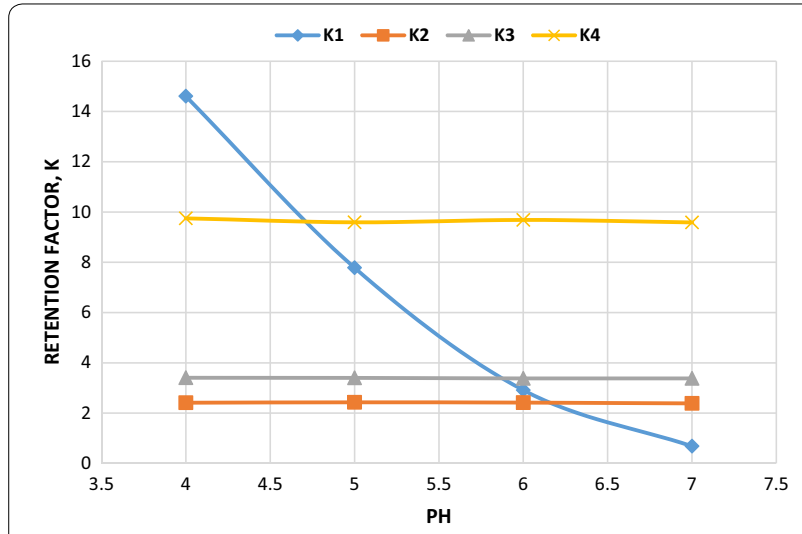

Fig. 3 Effect of different ratios of acetonitrile in the mobile phase on the elution of the studied compounds, the order of elution is: paritaprevir (PAR), dasabuvir (DAS), ritonavir (RIT), and ombitasvir (OMB)

\section{Specificity}

The specificity of the proposed HPLC method was assessed by comparing the spectrum of each drug in the sample with the reference drug spectrum using the diode array detector. Chromatograms obtained from standard solutions were also compared to those from the sample solutions, and interference was not observed in the presence of formulation excipients, indicating that the specificity of the method was satisfactory Table 5 .

\section{Limit of detection (LOD) and limit of quantitation (LOQ)}

The limit of detection and limit of quantitation were determined by diluting known concentrations of each drug until signal to noise ratios of approximately $3: 1$ and 10:1 were obtained, respectively. The LOD and LOQ of PAR, DAS, RIT and OMB, which represent the capability of the method to detect and quantify low concentrations, were 0.0024 and $0.0049 \mu \mathrm{g} / \mathrm{ml}, 0.00488$ and $0.0098 \mu \mathrm{g} /$ $\mathrm{ml}, 0.0521$ and $0.1042 \mu \mathrm{g} / \mathrm{ml}, 0.0065$ and $0.0130 \mu \mathrm{g} / \mathrm{ml}$, respectively. This result indicates the capability of the method to detect and quantify low concentrations. The results are summarized in Table 2.

\section{Linearity}

The linearity of the response of the detector for each drug was determined by plotting the response ratio (ratio of the peak area of the drug to that of the internal standard) versus the drug concentration and calculating the corresponding regression equation. The calibration curve was linear at concentrations of $2.5-60 \mu \mathrm{g} / \mathrm{ml}$ for PAR, 


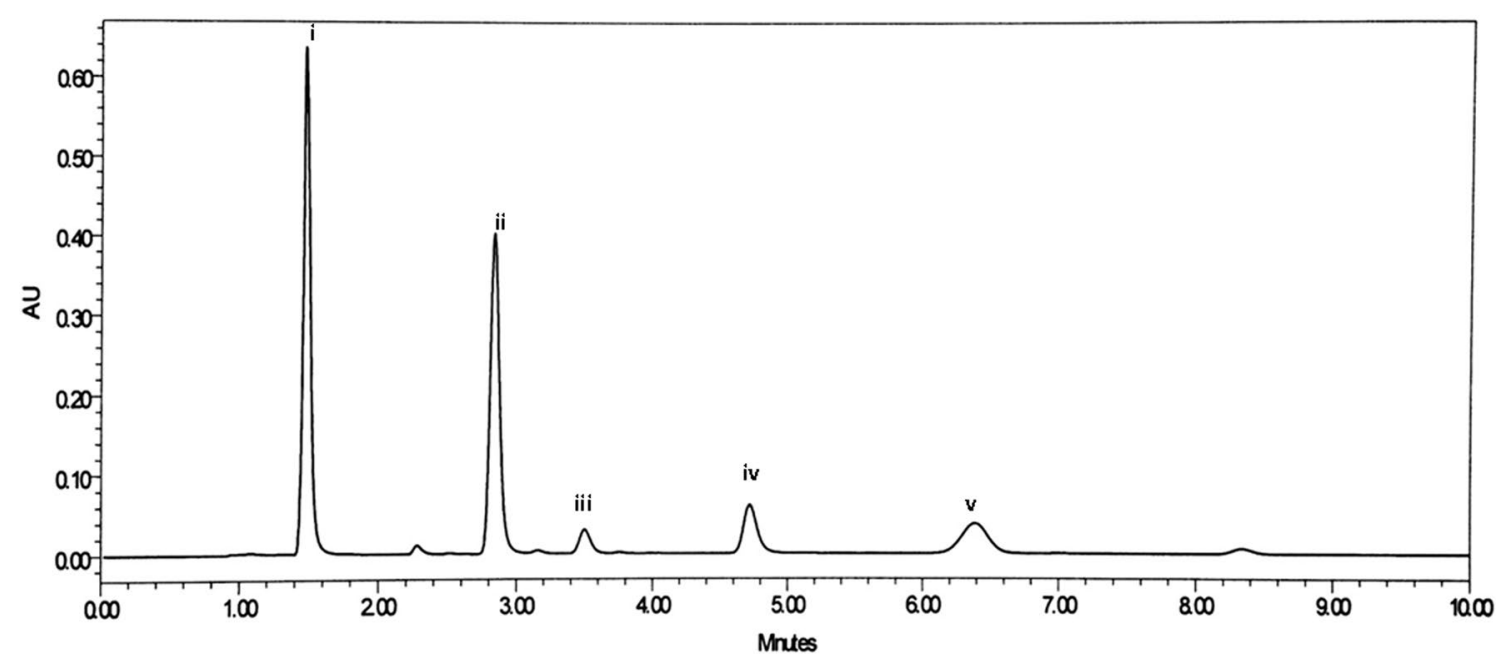

Fig. 4 A typical chromatogram of mixed standard solution: (i) $40 \mu \mathrm{g} / \mathrm{ml} \mathrm{PAR;} \mathrm{(ii)} 15 \mu \mathrm{g} / \mathrm{ml} \mathrm{DAS}$; (iii) $26.7 \mu \mathrm{g} / \mathrm{ml} \mathrm{RIT;} \mathrm{(vi)} 5 \mu \mathrm{g} / \mathrm{ml} \mathrm{SOR} \mathrm{(IS);} \mathrm{(v)} 6.7 \mu \mathrm{g} / \mathrm{ml}$ $\mathrm{OMB}$

Table 1 System suitability parameters for the determination of paritaprevir (PAR), dasabuvir (DAS), ritonavir (RIT), and ombitasvir (OMB) using the proposed HPLC method

\begin{tabular}{lllllll}
\hline Analyte & Retention time $\left.(\mathbf{m i n}) \mathbf{(}_{\mathbf{t}}\right)$ & Capacity factor $(\mathbf{k})$ & Selectivity $(\mathbf{a})$ & Resolution $\left(\mathbf{R}_{\mathbf{s}}\right)$ & Tailing $\left(\mathbf{T}_{\mathbf{f}}\right)$ & Efficiency (no. of theoretical plates) \\
\hline PAR & 1.476 & 1.73 & - & - & 1 & 2443 \\
DAS & 2.835 & 4.13 & 2.39 & 10.62 & 1.20 & 8211 \\
RIT & 3.499 & 5.33 & 1.29 & 4.25 & 1 & 5555 \\
SOR & 4.720 & 7.53 & 1.41 & 6.49 & 1.20 & 10,085 \\
OMB & 6.388 & 10.53 & 1.40 & 6.64 & 1.20 & 6632 \\
\hline
\end{tabular}

$1.25-30 \mu \mathrm{g} / \mathrm{ml}$ for DAS, $1.7-40 \mu \mathrm{g} / \mathrm{ml}$ for RIT and $0.42-$ $10 \mu \mathrm{g} / \mathrm{ml}$ for OMB. For all of the standard solutions, each concentration was injected in triplicate to obtain reproducible responses. According to the results of the regression analysis, which are given in Table 2, the method was linear, showing a correlation coefficient of $>0.999$.

The high values of the correlation coefficients $(r)$ and negligible intercepts (a) indicated that the linearity of the calibration graphs was acceptable. Sy/x is a measure of the extent of deviation between the observed (measured) $y$-values and calculated y-values. For example, low values of $S y / x$ indicate that the point lies close to the regression line. The standard deviation (SD) of the intercept (Sa) and slope $(\mathrm{Sb})$ were also calculated.

\section{Precision and accuracy}

The repeatability of the developed method (intra and inter-day precision), which was expressed as the \% RSD, and the accuracy, which was expressed as the \%Er, were determined by injecting three different standard solution sat each of the low, medium and high concentration levels on the same day for the intra-day study $(n=3)$ and the following two consecutive days for the inter-day studies $(n=9)$. As shown in Table 3 , the calculated \% RSD
Table 2 Regression and statistical parameters for the determination of DAAs using the proposed HPLC method

\begin{tabular}{lllll}
\hline & PAR & DAS & RIT & OMB \\
\hline $\begin{array}{lllll}\text { Linearity range } \\
(\mu \mathrm{g} / \mathrm{ml})\end{array}$ & $2.5-60$ & $1.25-30$ & $1.7-40$ & $0.42-10$ \\
$\mathrm{LOD}(\mu \mathrm{g} / \mathrm{ml})^{\mathrm{a}}$ & 0.0024 & 0.00488 & 0.0521 & 0.0065 \\
$\mathrm{LOQ}(\mu \mathrm{g} / \mathrm{ml})^{\mathrm{b}}$ & 0.0049 & 0.0098 & 0.1042 & 0.0130 \\
Intercept $_{\text {Slope }}$ & 0.0940 & 0.0525 & 0.0057 & 0.0124 \\
Correlation & 0.1233 & 0.2122 & 0.0144 & 0.1725 \\
$\quad$ coefficient $(\mathrm{r})$ & 0.9995 & 0.9998 & 0.9996 & 0.9997 \\
$\mathrm{~S}_{\mathrm{a}}^{\mathrm{c}}$ & 0.0415 & 0.0230 & 0.0031 & 0.0137 \\
$\mathrm{~S}_{\mathrm{b}}^{\mathrm{d}}$ & 0.0013 & 0.0015 & 0.0002 & 0.0084 \\
$\mathrm{~S}_{\mathrm{y} / \mathrm{x}}^{\mathrm{e}}$ & 0.0682 & 0.0378 & 0.0051 & 0.0016 \\
$\mathrm{~F}^{\mathrm{f}}$ & 8441.8243 & 20320.4610 & 9008.7822 & 11307.0622 \\
Significance $\mathrm{F}^{\mathrm{L}}$ & $8.4127 \mathrm{E}-08$ & $1.4525 \mathrm{E}-08$ & $7.3875 \mathrm{E}-08$ & $4.6902 \mathrm{E}-08$
\end{tabular}

Ombitasvir (OMB), paritaprevir (PAR), ritonavir (RIT), and dasabuvir (DAS)

a LOD: limit of detection

b LOQ: limit of quantitation

c $\mathrm{S}_{\mathrm{a}}$ : standard deviation of intercept

d $\mathrm{S}_{\mathrm{b}}$ : standard deviation of slope

e $\mathrm{S}_{\mathrm{y} / \mathrm{x}}$ :standard deviation of residuals

${ }^{f} \mathrm{~F}$ : variance ratio, equals the mean of squares due to regression divided by the mean of squares about regression (due to residuals) 
Table 3 Intra-day and inter-day precision and accuracy for the determination of paritaprevir (PAR), dasabuvir (DAS), ritonavir (RIT), and ombitasvir (OMB) using the proposed HPLC method

\begin{tabular}{|c|c|c|c|c|c|c|c|}
\hline \multirow[t]{2}{*}{ Compound } & \multicolumn{4}{|c|}{ Intraday precision and accuracy $(n=3)$} & \multicolumn{3}{|c|}{ Interday precision and accuracy $(n=9)$} \\
\hline & Standard concentration $(\mu \mathrm{g} / \mathrm{ml})$ & Mean $\%$ recovery \pm SD & $\operatorname{RSD}(\%)^{\mathrm{a}}$ & $\operatorname{Er}(\%)^{b}$ & Mean $\%$ recovery \pm SD & $\operatorname{RSD}(\%)^{a}$ & $\operatorname{Er}(\%)^{b}$ \\
\hline \multirow[t]{3}{*}{ PAR } & 5 & $100.53 \pm 0.599$ & 0.596 & -0.526 & $99.17 \pm 1.227$ & 1.237 & 0.831 \\
\hline & 25 & $99.11 \pm 0.133$ & 0.134 & 0.893 & $99.22 \pm 0.396$ & 0.399 & 0.781 \\
\hline & 50 & $101.39 \pm 0.250$ & 0.247 & -1.387 & $101.29 \pm 0.232$ & 0.229 & -1.288 \\
\hline \multirow[t]{3}{*}{ DAS } & 3 & $99.72 \pm 0.324$ & 0.326 & 0.727 & $98.78 \pm 0.567$ & 0.574 & 1.223 \\
\hline & 15 & $100.75 \pm 0.143$ & 0.142 & -0.752 & $100.51 \pm 0.271$ & 0.270 & -0.508 \\
\hline & 25 & $100.38 \pm 0.17$ & 0.17 & -0.384 & $100.45 \pm 0.352$ & 0.350 & -0.451 \\
\hline \multirow[t]{3}{*}{ RIT } & 3.3 & $101.19 \pm 1.183$ & 1.169 & -1.191 & $101.32 \pm 0.996$ & 0.983 & -1.316 \\
\hline & 16.7 & $100.67 \pm 0.069$ & 0.068 & -0.967 & $101.54 \pm 0.466$ & 0.459 & -1.542 \\
\hline & 33.3 & $100.92 \pm 0.053$ & 0.053 & -0.925 & $101.32 \pm 1.164$ & 1.149 & -1.315 \\
\hline \multirow[t]{3}{*}{$\mathrm{OMB}$} & 0.83 & $99.23 \pm 0.002$ & 0.002 & 0.768 & $99.71 \pm 1.612$ & 1.617 & 0.291 \\
\hline & 4.17 & $100.85 \pm 0.001$ & 0.001 & -0.852 & $100.99 \pm 0.312$ & 0.309 & -0.995 \\
\hline & 8.33 & $101.64 \pm 0.006$ & 0.006 & -1.637 & $101.66 \pm 0.386$ & 0.379 & -1.659 \\
\hline
\end{tabular}

a $\mathrm{RSD}(\%)$ : percentage relative standard deviation

${ }^{\mathrm{b}} \mathrm{Er}(\%)$ : percentage relative error

and $\%$ Er were within the acceptable range of values, $<2 \%$ for both \% Er and \% RSD.

\section{Robustness}

The robustness of the method was studied by making small but deliberate changes in the chromatographic parameters and evaluating the resulting \% RSD. The optimal injection volume $( \pm 5 \mu \mathrm{l})$, detection wavelength $( \pm 1 \mathrm{~nm})$, percentage of acetonitrile $( \pm 1 \mathrm{ml})$, mobile phase flow $( \pm 1 \mathrm{ml} / \mathrm{min})$ and $\mathrm{pH}$ of the mobile phase $( \pm 0.1$ unit) were studied by changing a single parameter while maintaining the others at a constant value. The \% RSD is provided in Table 4. Significant changes in chromatograms were not observed \% $\mathrm{RSD}<2 \%$, demonstrating the robustness of the developed method.

\section{Solution stability}

The stabilities of both standard and sample solutions were examined, and changes in the corresponding chromatographs were not observed after $24 \mathrm{~h}$ at room temperature and over 3 weeks in a refrigerator $\left(4^{\circ} \mathrm{C}\right)$.

Table 4 Robustness of the proposed HPLC method

\begin{tabular}{|c|c|c|c|c|c|c|c|c|}
\hline \multirow[t]{2}{*}{ Parameter } & \multicolumn{2}{|l|}{ PAR } & \multicolumn{2}{|l|}{ DAS } & \multicolumn{2}{|l|}{ RIT } & \multicolumn{2}{|l|}{ OMB } \\
\hline & $\begin{array}{l}\text { RSD \% of peak } \\
\text { areas }\end{array}$ & $\mathbf{k} \pm \mathrm{SD}$ & $\begin{array}{l}\text { RSD \% of peak } \\
\text { areas }\end{array}$ & $\mathrm{k} \pm \mathrm{SD}$ & $\begin{array}{l}\text { RSD \% of peak } \\
\text { areas }\end{array}$ & $\mathrm{k} \pm \mathrm{SD}$ & $\begin{array}{l}\text { RSD \% of peak } \\
\text { areas }\end{array}$ & $k \pm S D$ \\
\hline $\begin{array}{l}\text { Percentage of } \\
\text { acetonitrile } \\
\text { in the mobile } \\
\text { phase }[64,65 \\
\text { and } 66 \mathrm{ml}]\end{array}$ & 0.290 & $0.48 \pm 0.007$ & 0.177 & $2.08 \pm 0.005$ & 0.446 & $2.81 \pm 0.001$ & 0.335 & $6.11 \pm 0.002$ \\
\hline $\begin{array}{l}\text { pH of the aque- } \\
\text { ous phase [6.9, } \\
7 \text { and } 7.1]\end{array}$ & 0.363 & $0.53 \pm 0.011$ & 0.178 & $2.03 \pm 0.010$ & 0.413 & $2.73 \pm 0.001$ & 0.471 & $5.85 \pm 0.003$ \\
\hline $\begin{array}{l}\text { Flow rate }[0.9 \text {, } \\
1 \text {, and } 1.1 \mathrm{ml} / \\
\text { min] }\end{array}$ & 0.239 & $0.53 \pm 0.005$ & 0.182 & $2.12 \pm 0.005$ & 0.32 & $2.87 \pm 0.000$ & 0.579 & $6.25 \pm 0.003$ \\
\hline $\begin{array}{c}\text { Injection volume } \\
{[15,20,25 \mu \mathrm{l}]}\end{array}$ & 0.255 & $0.53 \pm 0.024$ & 0.141 & $1.97 \pm 0.026$ & 0.80 & $2.68 \pm 0.01$ & 0.314 & $5.66 \pm 0.007$ \\
\hline $\begin{array}{l}\text { Detection } \\
\text { wavelength } \\
{[253,254 \text { and }} \\
255 \mathrm{~nm}]\end{array}$ & 0.403 & $0.55 \pm 0.007$ & 0.089 & $1.99 \pm 0.003$ & 0.394 & $2.69 \pm 0.001$ & 0.580 & $5.75 \pm 0.002$ \\
\hline
\end{tabular}


Table 5 Assay of paritaprevir (PAR), dasabuvir (DAS), ritonavir (RIT) and ombitasvir (OMB) tablets by the proposed HPLC methods

\begin{tabular}{llll}
\hline \multicolumn{4}{l}{ Mean \% recovery \pm RSD $^{\mathbf{a}}$} \\
\hline PAR & DAS & RIT & OMB \\
\hline $101.89 \pm 0.264$ & $99.61 \pm 0.498$ & $101.93 \pm 0.862$ & $102.28 \pm 0.011$ \\
\hline
\end{tabular}

${ }^{a}$ Results are average of 6 experiments

\section{Analysis of pharmaceutical formulations}

The developed HPLC method with DAD was successfully applied to analyse the content of PAR, RIT and OMBin Viekirax ${ }^{\circledR}$ tablets and DAS in Exviera ${ }^{\circledR}$ tablets. Interfering peaks were not observed in the chromatogram of the marketed formulation, indicating that excipients used in the tablets did not interfere with the peaks of interest when the proposed method was employed. The mean $\%$ recovery of the drug content of the tablets was determined and was shown to range from 98 to $102 \%$. The results are reported in Table 5 .

\section{Conclusions}

A new method based on isocratic RP-HPLC with DAD was developed and validated for the simultaneous determination of paritaprevir, ombitasvir, ritonavir and dasabuvir in bulk and pharmaceutical formulations. The reliability assessment showed that the proposed method was linear, accurate, precise, reproducible, specific and robust. Moreover, all four drugs were successfully resolved and quantified within a single analytical run with a short operating time (the elution time of the last peak was $6.3 \mathrm{~min}$ ). Therefore, the developed method can be used in quality control studies, in which cost and time are concerning factors.

\section{Abbreviations}

HPLC-DAD: high performance liquid chromatography-diode array detection ion; PAR: paritaprevir; OMB: ombitasvir; DAS: dasabuvir; RIT: ritonavir.

\section{Authors' contributions}

NZ designed the study, participated in discussing the results, and revised the manuscript. HM conducted the optimization and assay validation studies. AS performed the assays and prepared the manuscript. All authors read and approved the final manuscript.

\section{Author details}

${ }^{1}$ College of Pharmacy, Department of Pharmaceutical Chemistry, King Saud University, P.O. Box 22452, Riyadh 11495, Saudi Arabia. ${ }^{2}$ Faculty of Pharmacy, Department of Pharmaceutical Analytical Chemistry, University of Alexandria, El-Messalah, Alexandria 21521, Egypt.

\section{Acknowledgements}

This research project was supported by a grant from the "ResearchCenter of the Center for Female Scientific and MedicalColleges," Deanship of Scientific Research, King Saud University.

\section{Competing interests}

The authors declare that they have no competing interests.

Received: 27 October 2016 Accepted: 14 December 2016

Published online: 03 January 2017

\section{References}

1. Cooke GC, Lemoine M, Thursz M, Gore C, Swan T, Kamarulzaman A, DuCros P, Ford N (2013) Viral hepatitis and the global burden of disease: a need to regroup. J Viral Hepat 20:600-601

2. Berenguer M, López-Labrador FX, Wright TL (2001) Hepatitis C and liver transplantation. J Hepatol 35:666-678

3. World Health Organization (2005) Hepatitis C, Fact sheet 164, updated July 2015. http://www.who.int/mediacentre/factsheets/fs164/en/. Retrieved 3 Dec 2015

4. Hoofnagle J (2002) Course and outcome of hepatitis C. Hepatol 36:S21-S29

5. Al-Faleh FZ, Huraib S, Sbeih F, Al-Karawi M, Al-Rashed R, Al-Mofleh IA, Sougiyyah M, Shaheen M, Ramia S (1995) Hepatitis C virus genotypes in patients with chronic liver disease and haemodialysis patients from Saudi Arabia. J Viral Hepat 2:293-296

6. Pawlotsky J (2014) New hepatitis C therapies: the toolbox, strategies, and challenges. Gastroenterology 146:1176-1192

7. Gutierrez J, Lawitz E, Poordad F (2015) Interferon-free, direct-acting antiviral therapy for chronic hepatitis C. J Viral Hepat 22:861-870

8. Jack K (2015) Advances in treatments for hepatitis C. Br J Health Care Manag 21:408-413

9. Majumdar A, Kitson MT, Roberts SK (2015) Treatment of hepatitis C in patients with cirrhosis: remaining challenges for direct-acting antiviral therapy. Drugs 5:823-834

10. Schinazi R, Halfon P, Marcellin P, Asselah T (2014) HCV direct-acting antiviral agents: the best interferon-free combinations. Liver Int 34:69-78

11. Zhang X (2016) Direct anti-HCV agents. Acta Pharm Sinica B 6(1):26-31

12. The medical letter on drugs and therapeutics. A 4-drug combination (Viekira Pak) for hepatitis C. J Am Med Assoc 2015;313: 1857-1858

13. FDA, US food and drug administration. FDA approves Viekira Pak to treat hepatitis C.FDANews release, Dec. 19, 2014. http://www.fda.gov/NewsEvents/ Newsroom/PressAnnouncements/ucm427530.htm. Retrieved 8 Dec 2015

14. FDA, US food and drug administration. FDA approves Technivie for treatment of chronic hepatitis C genotype 4. FDA News release, 24 July 2015

15. Gutleben W, Tuan ND, Stoiber H, Dierich MP, Sarcletti M, Zemann A (2001) Capillary electrophoretic separation of protease inhibitors used in human immunodeficiency virus therapy. J Chromatogr A 922:313-320

16. Breadmore MC, Theurillat $R$, Thormann W (2004) Determination of ribavirin in human serum and plasma by capillary electrophoresis. Electrophoresis 25:1615-1622

17. Rao BV, Vidyadhara S, Babu RR, Kumar BP, Kumar GK (2014) Analytical method development and validation for simultaneous estimation of lopinavir and ritonavir by RP-HPLC. Int J Res Dev Pharm L Sci 15:1074-1079

18. Jagadeeswaran M, Gopal N, Kumar KP, Kumar TS (2012) Quantitative estimation of lopinavir and ritonavir in tablets by RP-HPLC method. Pharm Anal Acta 3:3-5

19. Pabolu HK, Konidala SK (2013) New validated RP-HPLC method for the determination of ritonavir in bulk and pharmaceutical dosage form. Int J Pharm Pharm Sci 5:556-559

20. Kumar KV, Sudhakar M, Reddy YP, Malleshwari P, Hafeez SK (2014) RP-HPLC method development and validation for simultaneous estimation of lopinavir and ritonavir in dosage form and in plasma. Int J Pharm Res Rev 3:1-8

21. Sun H, Wang H, Ge X, Qin X (2011) Simultaneous determination of the combined drugs ribavirin and ceftriaxone sodium in human urine by HPLC-DAD. Int J Sci Innov Dis 1:216-225

22. Rezk MR, Basalious EB, Karim IA (2015) Development of a sensitive UPLCESI-MS/MS method for quantification of sofosbuvir and its metabolite, GS-331007, in human plasma: application to a bioequivalence study. J Pharm Biomed Anal 114:97-104

23. Shi X, Zhu D, Lou J, Zhu B, Hu AR, Gan D (2015) Evaluation of a rapid method for the simultaneous quantification of ribavirin, sofosbuvir and 
its metabolite in rat plasma by UPLC-MS/MS. J Chromatogr B Anal Technol Biomed Life Sci 1002:353-357

24. Killi GD, Maddinapudi RK, Dinakaran SK (2014) A novel validated UPLC method for quantitation of lopinavir and ritonavir in bulk drug and pharmaceutical formulation with its impurities. Braz J Pharm Sci 50:301-308

25. Hendrikx JJ, Hillebrand MJ, Thijssen B, Rosing H, Schinkel AH, Schellens $J H$, Beijnen JH (2011) A sensitive combined assay for the quantification of paclitaxel, docetaxel and ritonavir in human plasma using liquid chromatography coupled with tandem mass spectrometry. J Chromatogr B Anal Technol Biomed Life Sci 879:2984-2990

26. Aouri M, Moradpour D, Cavassini M, Mercier T, Buclin T, Csajka C, Telenti A, Rauch A, Decosterd TA (2013) Multiplex liquid chromatography-tandem mass spectrometry assay for simultaneous therapeutic drug monitoring of ribavirin, boceprevir, and telaprevir. Antimicrob Agents Chemother 57:3147-3158

27. Abdelhay MH, Gazy AA, Shaalan RA, Ashour HK (2012) Validated stabilityindicating HPLC and HPTLC methods for the determination of ritonavir in bulk powder and in capsules. J Food Drug Anal 20:963-973

28. Sadanshio PP, Wankhede SB, Chaudhari PD (2015) A validated stability indicating HPTLC method for estimation of ribavirin in capsule in presence of its alkaline hydrolysis degradation product. Anal Chem Lett 4:343-358

29. ICH Guideline (2005), Q2(R1): validation of analytical procedure: text and methodology. London

\section{Submit your manuscript to a SpringerOpen ${ }^{\circ}$ journal and benefit from:}

- Convenient online submission

\section{- Rigorous peer review}

- Immediate publication on acceptance

- Open access: articles freely available online

- High visibility within the field

- Retaining the copyright to your article 